\title{
High Prevalence of Vitamin D Deficiency in Japanese Female Patients with Graves' Disease
}

\author{
Hiroyuki YAMASHITA, ShIRo NOGUCHI, KeIsUKe TAKATSU, EISUKe KOIKE, TsuKaSA MURAKAMI, \\ Shin WATANABE, Shinya UCHINO, Hiroto YAMASHITA and Hitoshi KAWAMOTO
}

Noguchi Thyroid Clinic and Hospital Foundation, 6-33 Noguchi-Nakamachi, Beppu, Oita 874-0932, Japan

\begin{abstract}
We reported previously that vitamin D deficiency is a causal mechanism of postoperative tetany in patients with Graves' disease. The aim of the present study was to determine the prevalence of vitamin D deficiency by reviewing serum $25(\mathrm{OH}) \mathrm{D}$ levels in 208 patients with Graves' disease (146 women, 62 men) during a 1 year period. Serum $25(\mathrm{OH}) \mathrm{D}$ levels were significantly lower $(\mathrm{p}<0.001)$ in female Graves' patients $(31.8 \pm 13.3 \mathrm{nmol} / \mathrm{l})$ than in male patients $(41.3 \pm 15.0 \mathrm{nmol} / \mathrm{l})$. Vitamin D deficiency (defined as a serum $25(\mathrm{OH}) \mathrm{D}$ value below $25 \mathrm{nmol} / \mathrm{l}$ ) was found in $40 \%$ of female patients and in $18 \%$ of male patients $(\mathrm{p}<0.005)$. There was a significant seasonal variation in the $25(\mathrm{OH}) \mathrm{D}$ concentrations in female patients [amplitude 6.38 (95\% CI, 5.42-7.56)], with values below $25 \mathrm{nmol} / 1$ found in $58 \%$ of female patients during the winter months. There were significant $(\mathrm{p}<0.001)$ differences in serum $25(\mathrm{OH}) \mathrm{D}$ levels between age groups in the female patients. The concentrations were lowest in patients in their twenties $(25.1 \pm 8.2 \mathrm{nmol} / \mathrm{l})$ and highest in patients in their fifties and sixties $(43.2 \pm 13.7 \mathrm{nmol} / \mathrm{l})$. Serum $25(\mathrm{OH}) \mathrm{D}$ concentrations might be monitored in patients with Graves' disease during antithyroid drug therapy, and vitamin D and/or calcium supplements are recommended for patients with vitamin D deficiency.
\end{abstract}

Key words: Graves' disease, Vitamin D deficiency, Vitamin D, seasonal variation

(Endocrine Journal 48: 63-69, 2001)

THYROIDECTOMY is an established treatment for patients with Graves' disease. Tetany is one of several postoperative complications and is usually caused by hypocalcemia. In previous studies we have shown that postoperative tetany occurs in patients with secondary hyperparathyroidism caused by deficiencies in calcium and vitamin $\mathrm{D}$ due to increased demand for bone restoration after medical therapy concomitant with hypoparathyroidism after surgery [1-4].

We observed a relatively high incidence of vitamin D deficiency in female patients with Graves' disease

Received: October 3, 2000

Accepted: November 24, 2000

Correspondence to: Hiroyuki YAMASHITA, M.D., Noguchi Thyroid Clinic and Hospital Foundation, 6-33 NoguchiNakamachi, Beppu, Oita 874-0932, Japan
[4]. This has important clinical implications for the overall management of Graves' patients with thyrotoxic bone disease. Patients treated for hyperthyroidism with antithyroid drugs show significant increase in bone mineral density [5]. However, recovery of bone mineral density may not occur in Graves' patients with vitamin D deficiency, making vitamin $\mathrm{D}$ deficiency a risk factor for osteoporosis and bone fractures in such patients [6]. Cummings et al. [7] reported previous hyperthyroidism to be a risk factor for hip fracture in Caucasian women based on a large cohort study. Several studies have reported a high prevalence of vitamin D deficiency in selected populations including nursing home residents and persons over age $65[8,9]$. There have been few studies, however, of seasonal variations [10-14] in vitamin D levels in Graves' patients.

We assessed the prevalence of vitamin $D$ deficiency 
in a large number of Graves' patients by reviewing serum $25(\mathrm{OH}) \mathrm{D}$ levels during a 1 year period. A better understanding of the prevalence of vitamin $D$ deficiency may alter current medical protocols for treatment of patients with Graves' disease.

\section{Patients and Methods}

\section{Patients}

Of 509 (383 women, 126 men) patients with Graves' disease who underwent subtotal thyroidectomy in 1997, we selected 208 patients ( 146 women, 62 men) who were euthyroid (normal levels of both free triiodothyronine (FT3) and free thyroxine (FT4)) preoperatively. Thyroid function influences the serum concentration of vitamin D [12]. None of the patients had received drugs known to interfere with vitamin $\mathrm{D}$ or calcium levels. The mean age of the patients was 34 years (range, 13 to 69 years). Duration of the euthyroid period was obtained from clinical records. Diagnosis of Graves' disease was made on the basis of clinical findings, elevated serum levels of FT3 and FT4 with an undetectable TSH concentration, positive immunoreactivity with an anti-TSH receptor antibody, and an elevated rate of ${ }^{131}$ I iodine uptake. The protocol used was approved by the staff at the Noguchi Thyroid Clinic , Beppu City, Japan.

\section{Laboratory tests}

Blood and urine samples were collected from each patient after an overnight fast on the day before surgery. Serum levels of alkaline phosphatase (normal range, 36-92 U/1), total calcium (2.20-2.54 $\mathrm{mmol} / \mathrm{l})$, albumin $(35-48 \mathrm{~g} / \mathrm{l})$, and inorganic phosphate $(0.81-1.45 \mathrm{mmol} / \mathrm{l})$ were measured by routine automated procedures. Serum magnesium concentrations $(0.74-0.95 \mathrm{mmol} / \mathrm{l})$ were determined with an electrolyte analyzer (Nova Biomedical, Waltham, MA, USA). The corrected calcium level ( $\mathrm{mmol} / \mathrm{l})$ was calculated with the following formula: \{calcium concentration $(\mathrm{mg} / \mathrm{dl})$ plus (4-albumin concentration $(\mathrm{g} / \mathrm{dl}))\} \times 0.250$. The FT4 (normal range, 9.0-21.9 pmol/1), FT3 (3.4-6.3 pmol/l) and TSH (0.30-3.50 $\mu \mathrm{U} / \mathrm{l})$ levels were determined with a commercially available chemiluminescent immunoassay (Ciba Corning Diagnostics Corp., Medfield, MA, USA).
Thyrotropin-binding inhibitory immunoglobulins (TBII) (normal range, -15-8\%) levels were measured with a TRAb assay kit (INCSTAR Corp., Stillwater, MN). Serum 25(OH)D levels (normal range, $25-137 \mathrm{nmol} / \mathrm{l}$ ) were measured with a competitive protein-binding assay using high-performance liquid chromatography purification with intra- and interassay coefficients of variation of $5.8 \%$ and $12.6 \%$, respectively [15].

\section{Statistical analysis}

Data are expressed as mean \pm standard deviation (SD). Continuous variables for men and women were compared by Student's $t$-test or Wilcoxon's test as appropriate. Cross-tabulated data were analyzed with the chi-square test. Correlation was tested by calculating Pearson's correlation coefficient. The possible seasonal variations in serum $25(\mathrm{OH}) \mathrm{D}$ levels were evaluated with the simple cyclic regression equation (cosinor methods [16]): $\mathrm{y}=\mathrm{a} 0+\mathrm{a} 1 \operatorname{SIN}(2 \pi \cdot(\mathrm{x}-$ a2)/12), where $y$ is the individual $25(\mathrm{OH}) \mathrm{D}$ level $(\mathrm{nmol} / \mathrm{l}), \mathrm{x}$ is the time of year in terms of month (January, month 1), and $\mathrm{a} 0$ is the mean of $\mathrm{y}, \mathrm{a} 1$ is the amplitude of the oscillation about $\mathrm{a} 0$, and $\mathrm{a} 2$ is the phase constant. These statistical analyses were performed with SAS-JMP ver 3.1R software for the Macintosh (SAS Institute Inc., Cary, NC).

\section{Results}

Biochemical data for the 146 female and 62 male patients with Graves' disease are shown in Table 1. Duration of the euthyroid period ranged from 1202 months (mean, 14 months; median, 1 month), and there were no significant differences in duration between the sexes. No significant differences were found between the sexes in thyroid hormone status, TBII, serum phosphate, corrected calcium, ionized calcium, or magnesium levels, but there were significant differences in serum alkaline phosphatase and $25(\mathrm{OH}) \mathrm{D}$ concentrations.

Serum 25(OH)D values are shown in Fig. 1 according to the month of year. The sine curve indicates the best fit of serum $25(\mathrm{OH}) \mathrm{D}$ concentration vs time. Serum levels of $25(\mathrm{OH}) \mathrm{D}$ were the lowest in March and highest in September. There was a significant seasonal variation in $25(\mathrm{OH}) \mathrm{D}$ concentration 
Table 1. Clinical and preoperative biochemical data of study patients

\begin{tabular}{llll}
\hline Parameter & $\begin{array}{l}\text { Female } \\
\mathrm{n}=146\end{array}$ & $\begin{array}{l}\text { Male } \\
\mathrm{n}=62\end{array}$ & $p$ \\
\hline Age $(\mathrm{yr})$ & $\left.33.5 \pm 12.4^{\mathrm{a}}\right)$ & $35.8 \pm 12.5$ & $\mathrm{NS}$ ) \\
FT3 (pmol/l) & $5.07 \pm 1.00$ & $5.13 \pm 0.83$ & $\mathrm{NS}$ \\
FT4 $(\mathrm{pmol} / \mathrm{l})$ & $14.1 \pm 4.2$ & $14.6 \pm 2.9$ & $\mathrm{NS}$ \\
TSH $(\mu \mathrm{U} / \mathrm{ml})$ & $1.04 \pm 2.90$ & $0.81 \pm 2.98$ & $\mathrm{NS}$ \\
TBII $(\%)$ & $30.9 \pm 25.4$ & $38.1 \pm 24.7$ & $\mathrm{NS}$ \\
Euthyroid period (months) & $13.7 \pm 23.9$ & $13.9 \pm 36.6$ & $\mathrm{NS}$ \\
Serum calcium (mmol/l) & $2.36 \pm 0.09$ & $2.41 \pm 0.10$ & $\mathrm{p}<0.001$ \\
Serum calcium (albumin corrected) & $2.48 \pm 0.08$ & $2.49 \pm 0.09$ & $\mathrm{NS}$ \\
Ionized calcium (mmol/l) & $1.21 \pm 0.05$ & $1.22 \pm 0.05$ & $\mathrm{NS}$ \\
Serum phosphate (mmol/l) & $1.38 \pm 0.16$ & $1.33 \pm 0.19$ & $\mathrm{NS}$ \\
Serum magnesium (mmol/l) & $0.82 \pm 0.05$ & $0.83 \pm 0.05$ & $\mathrm{NS}$ \\
Alkaline phosphatase (U/1) & $135 \pm 69$ & $179 \pm 104$ & $\mathrm{p}<0.001$ \\
25(OH)D nmol/1 & $31.8 \pm 13.3$ & $41.3 \pm 15.0$ & $\mathrm{p}<0.001$ \\
\hline
\end{tabular}

a) Values are given as mean $\pm \mathrm{SD}$.

b) Not significant.

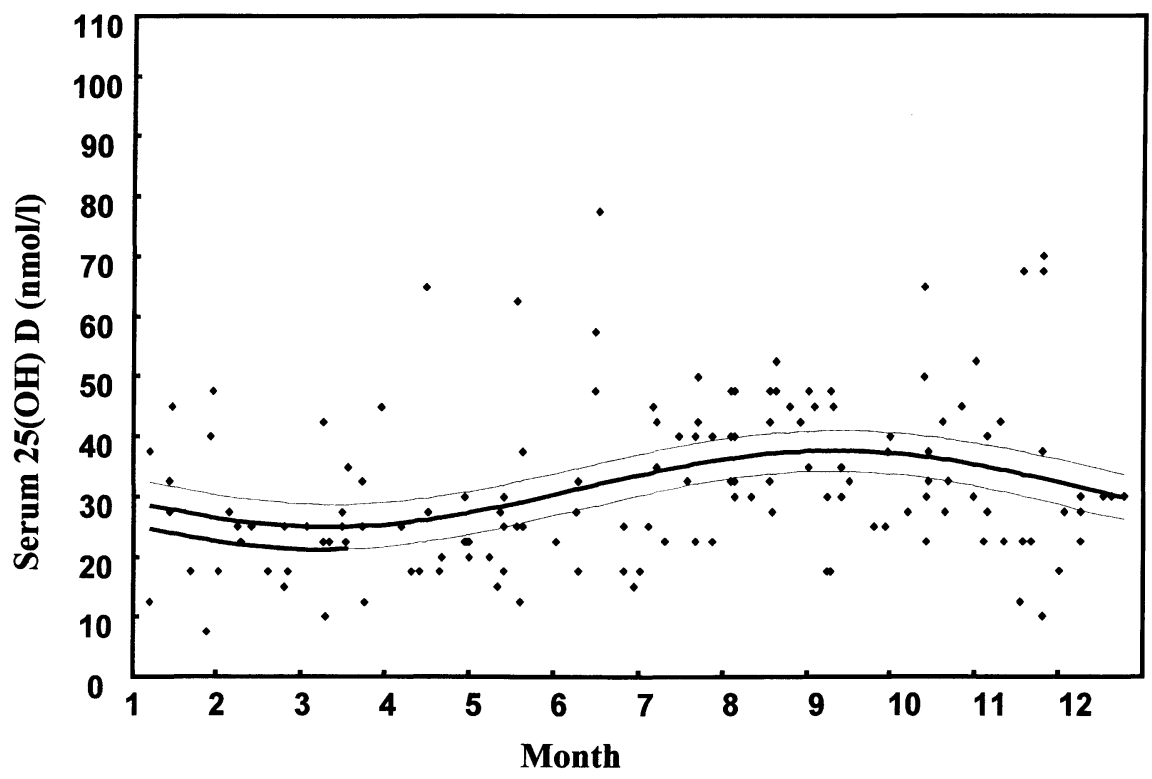

Fig. 1. Serum $25(\mathrm{OH}) \mathrm{D}$ values in 208 Graves' patients according to month. There were significant seasonal changes in serum 25(OH)D levels [amplitude 6.28 (95\% C.I., 5.36-7.24)].

[amplitude 6.28 (95\% confidence interval (CI), 5.367.24)]. When patients were grouped by sex, there were significant seasonal changes in $25(\mathrm{OH}) \mathrm{D}$ levels only in female patients [amplitude 6.38 (95\% CI, 5.42-7.56)]. There was a significant difference in the percentage of patients with vitamin $\mathrm{D}$ deficiency between the sexes $(17.8 \%$ vs $39.7 \%$, respectively; $\mathrm{p}<0.005$ ) (Fig. 2). Vitamin D deficiency is defined as a serum $25(\mathrm{OH}) \mathrm{D}$ level below $25 \mathrm{nmol} / \mathrm{l}$ according to the Special Reference Laboratories' norms. Among females, more than $50 \%$ of patients were vitamin D deficient between January and May. Figs. 3 and 4 show the serum 25(OH)D levels and percentages of vitamin $\mathrm{D}$ deficiency by age. Among female patients, those in their twenties had the lowest $25(\mathrm{OH}) \mathrm{D}$ levels and the highest percentage of vitamin 

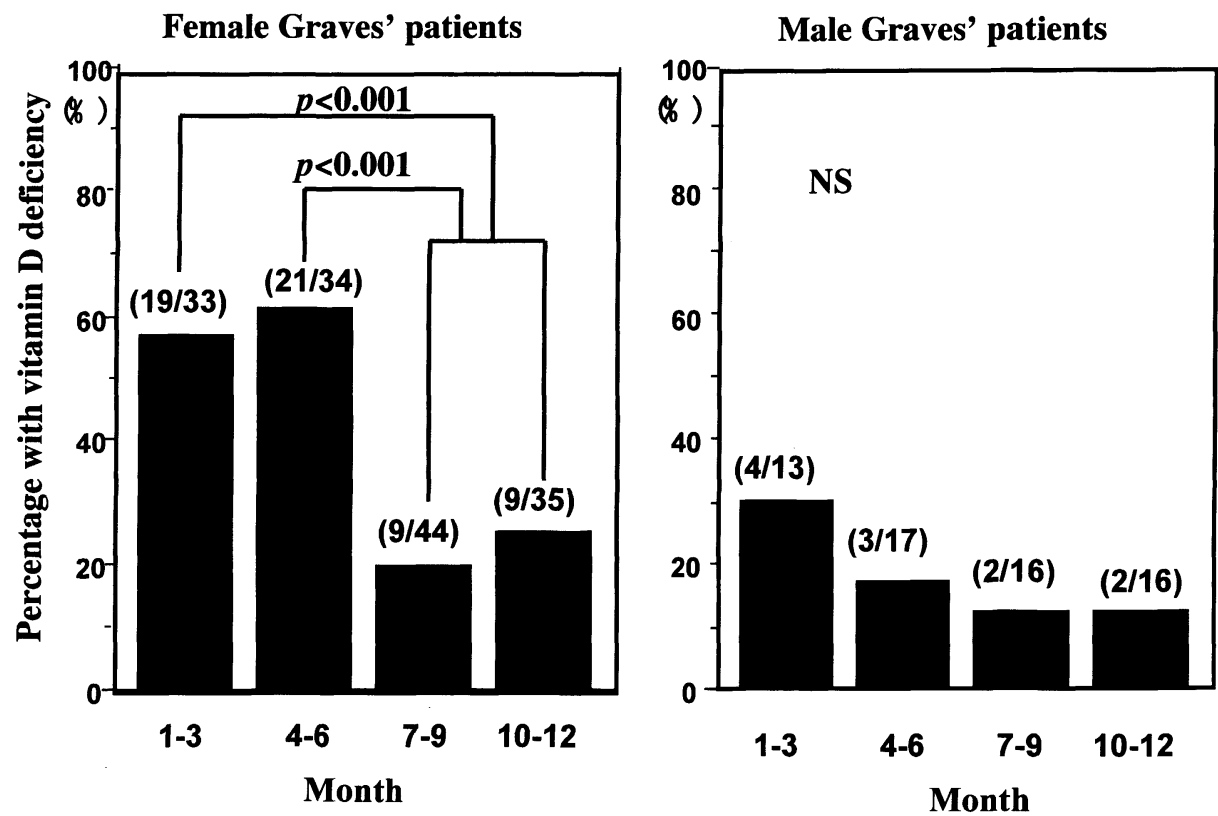

Fig. 2. Difference in the percentage of vitamin D deficiency between female $(n=146)$ and male $(n=62)$ Graves' patients. Vitamin D deficiency is defined as a serum $25(\mathrm{OH}) \mathrm{D}$ value below $25 \mathrm{nmol} / \mathrm{l}$.
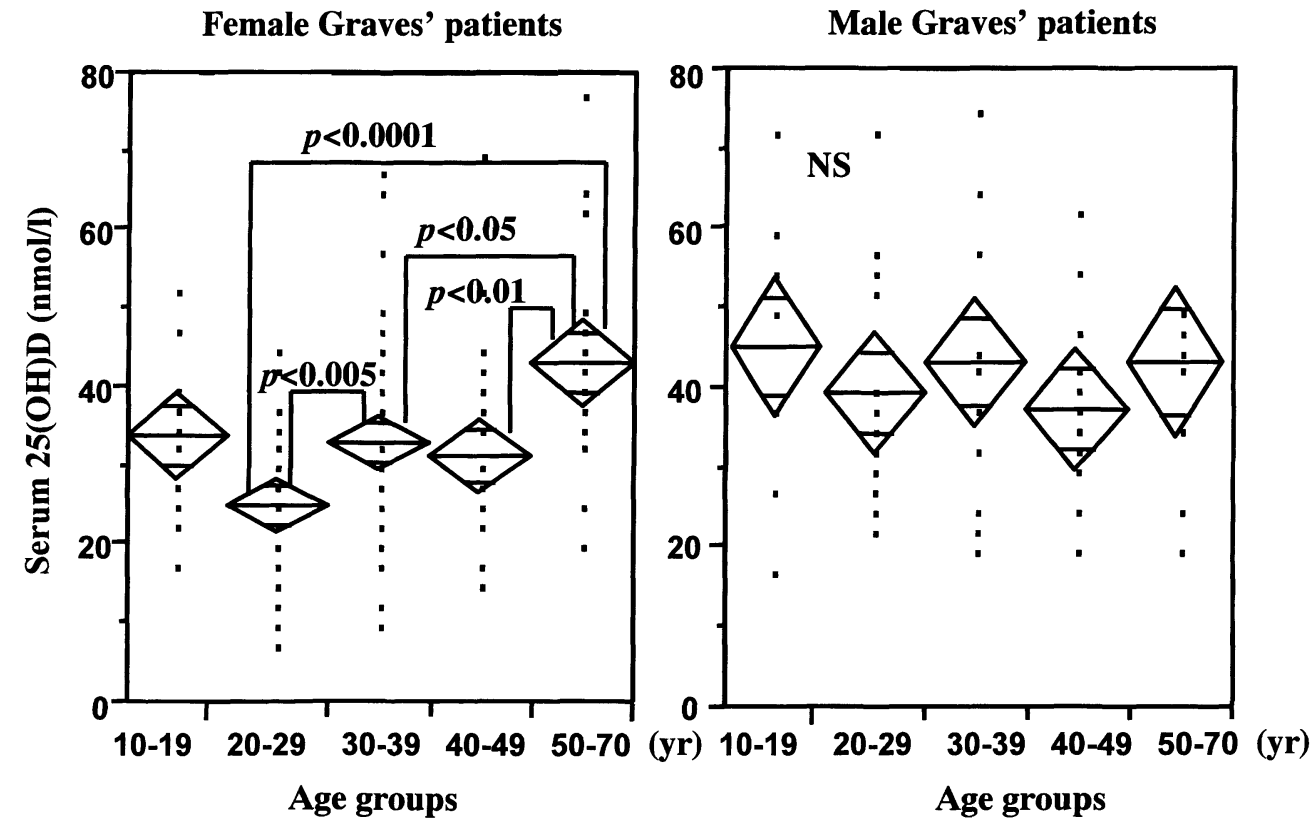

Fig. 3. Serum $25(\mathrm{OH}) \mathrm{D}$ levels in female $(n=146)$ and male $(n=62)$ Graves' patients according to age.

D deficiency. There was no relation between the duration of euthyroid period and serum 25(OH)D levels. Serum 25(OH)D levels were significantly $(p<0.001)$ correlated with serum calcium levels (Fig. 5). There were no significant differences in serum calcium, corrected calcium, alkaline phosphatase concentrations, or thyroid function between the four seasonal periods for either female or male patients (data not shown). 

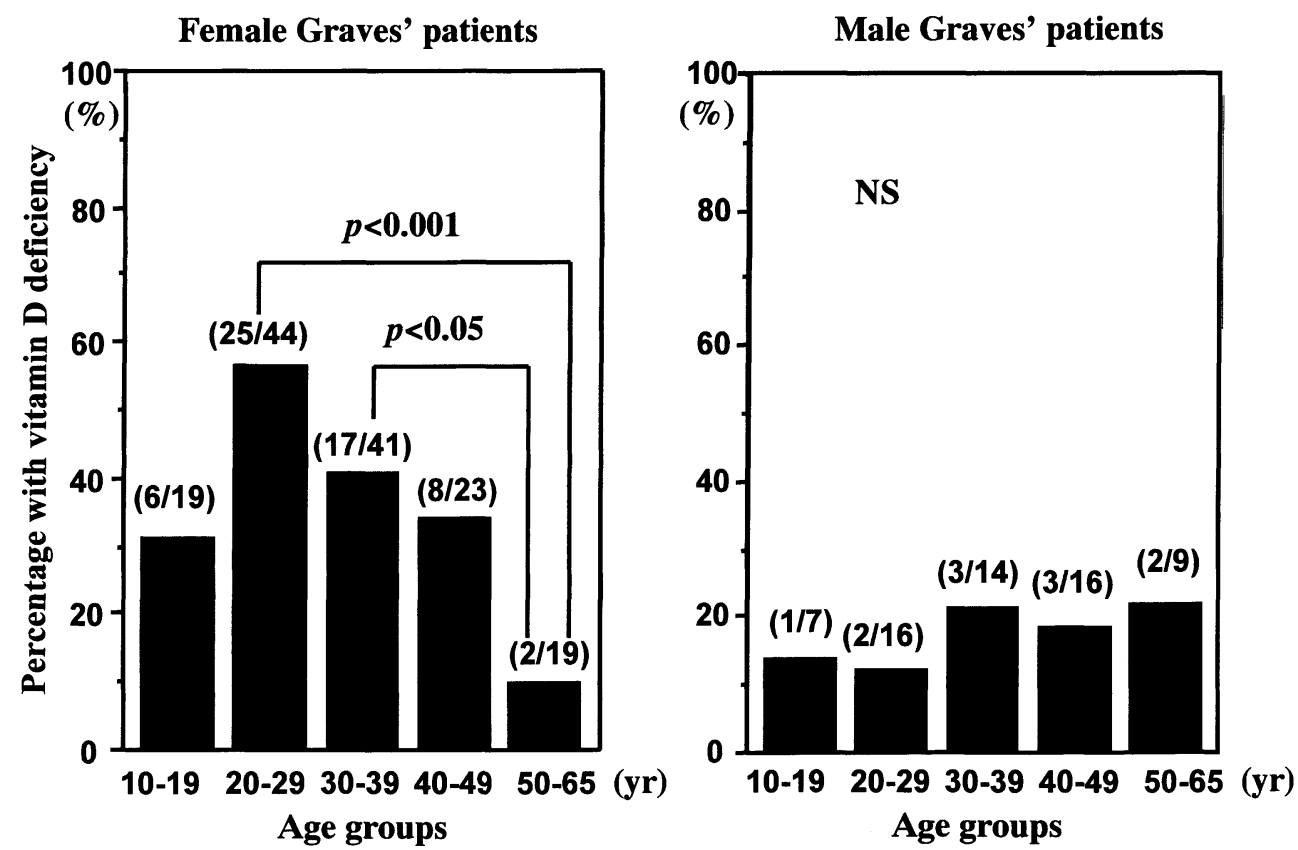

Fig. 4. Percentage female $(n=146)$ and male $(n=62)$ Graves' patients with vitamin $D$ deficiency sorted by age. Vitamin $D$ deficiency is defined as a serum $25(\mathrm{OH}) \mathrm{D}$ value below $25 \mathrm{nmol} / \mathrm{l}$.

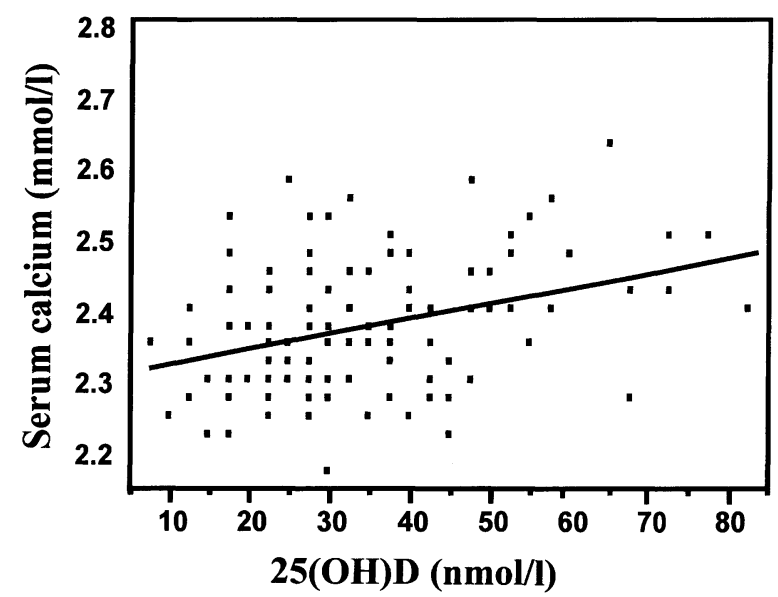

Fig. 5. Positive correlation between serum $25(\mathrm{OH}) \mathrm{D}$ and calcium values $(\mathrm{p}<0.0001)$.

\section{Discussion}

We observed relatively low concentrations of serum 25(OH)D in Graves' disease patients; the mean concentration was $41 \mathrm{~mol} / \mathrm{l}$ in men and $32 \mathrm{~mol} / \mathrm{l}$ in women. Kobayashi et al. [17] reported a mean serum $25(\mathrm{OH}) \mathrm{D}$ level of $59.4 \mathrm{nmol} / 1$ based on a study of 758 healthy Japanese subjects over a 1 year period. A low serum $25(\mathrm{OH}) \mathrm{D}$ concentration is the most significant diagnostic marker of vitamin D deficiency. Previous studies have shown normal [12-14], slightly decreased [10], or markedly decreased [11] serum 25(OH)D levels in hyperthyroid patients. In all of these studies, serum 25(OH)D levels were measured in untreated patients, but one study by MacFarlane et al. [13] showed serum 25(OH)D levels to be unchanged following oral carbimazole therapy. The discrepancies between these studies can be explained by differences in the selection of patients, dietary vitamin D intake, exposure to sunlight, and seasonal variations.

Although several authors have reported higher serum levels of $25(\mathrm{OH}) \mathrm{D}$ in normal men than in normal women $[17,18]$, data has not been available for patients with Graves' disease. In the present study, female Graves' patients had lower serum 25(OH)D levels than did their male counterparts. The lower serum 25(OH)D levels in women may be explained in part by the fact that females tend to avoid ultraviolet rays and use sunscreen [19] mainly because of cosmetic concern, and that males tend to have more outdoor occupations [20]. Our observation that female patients in their twenties had the lowest 25(OH)D levels (Fig. 3) supports our hypothesis. 
This is of clinical importance, because the risk of osteoporosis after menopause may increase since peak bone mass is usually achieved by approximately 30 years of age.

Seasonal variations in $25(\mathrm{OH}) \mathrm{D}$ levels have been observed in normal adults [17, 21-23], children [22], and elderly subjects [24], indicating an essential role of direct UV exposure in maintaining normal $25(\mathrm{OH}) \mathrm{D}$ levels. We also found seasonal variations in $25(\mathrm{OH}) \mathrm{D}$ concentrations in patients with Graves' disease; high levels were observed during summer and low levels were observed during winter (Fig. 1).

Accelerated bone metabolism with a negative calcium balance has been observed frequently in the hyperthyroid state. Longitudinal studies of patients treated for hyperthyroidism have produced conflicting data but, on the whole, suggest that thyrotoxic bone loss is potentially reversible $[5,25]$. In some patients, vitamin D deficiency can be induced if vitamin $D$ and calcium supplements are inadequate to maintain the rate of bone mineralization during the increased bone formation phase after antithyroid drug therapy. It is probable, but not proven, that bone mineral density cannot be recovered in such patients.

The low levels of $25(\mathrm{OH}) \mathrm{D}$ can also be attributed to increased metabolic clearance of $25(\mathrm{OH}) \mathrm{D}$. Clements et al. [26] proposed a new mechanism for vitamin $\mathrm{D}$ depletion, where calcium deficiency results in accelerated metabolism of $25(\mathrm{OH}) \mathrm{D}$. GasconBarré et al. [27] reported that patients with urolithiasis placed on low calcium diets ( $300 \mathrm{mg}$ daily) had significantly lower levels of $25(\mathrm{OH}) \mathrm{D}$ and sig- nificantly higher levels of $1,25(\mathrm{OH})_{2} \mathrm{D}$ than those receiving high dietary calcium (1000 $\mathrm{mg}$ daily). It is clear that the increased clearance of $25(\mathrm{OH}) \mathrm{D}$ in Graves' patients may explain the development of vitamin D deficiency when the supply of vitamin D is limited. Furthermore, steatorrhea in the hyperthyroid state may reduce the intestinal reabsorption of vitamin D metabolites in the enterohepatic circulation leading to increased loss of vitamin D metabolites [28].

In Japan, the mean daily calcium intake is $387 \mathrm{mg}$ in young persons and $518 \mathrm{mg}$ in elderly persons (the recommended intake for adults is $600 \mathrm{mg}$ daily) [29]. Since their diet is not fortified with vitamin D, Japanese patients with Graves' disease may be more susceptible to developing calcium and vitamin D deficiencies under their increased requirements. This is the first report of vitamin D status in a large number of patients with Graves' disease, but it provides limited information about calcium, vitamin $\mathrm{D}$, and bone metabolism. Dietary calcium and vitamin $\mathrm{D}$, skin production of vitamin $\mathrm{D}$, parathyroid hormone, and their relation to bone mineral density must be studied further.

In conclusion, we found a high prevalence of vitamin D deficiency in Japanese female Graves' patients. Therefore, vitamin D and/or calcium supplemention is to be recommend for patients with vitamin $\mathrm{D}$ deficiency undergoing antithyroid drug therapy. Vitamin D replacement therapy is simple, may reduce the risk of postoperative tetany, and also may increase bone mineral density during antithyroid drug therapy.

\section{References}

1. Yamashita H, Noguchi S, Tahara K, Watanabe S, Uchino S, Kawamoto H, Toda M, Murakami N (1997) Postoperative tetany in patients with Graves' disease: a risk factor analysis. Clin Endocrinol (Oxf) 47: 71-77.

2. Yamashita H, Noguchi S, Shiiba M, Murakami T, Watanabe S, Uchino S, Kawamoto H, Toda M (1998) Prediction of postoperative tetany in patients with Graves' disease: a prospective study. Thyroidol Clin Exp 10: 293-296.

3. Yamashita H, Murakami T, Noguchi S, Shiiba M, Watanabe S, Uchino S, Kawamoto H, Toda M, Murakami N (1999) Postoperative tetany in Graves' disease: Important role of vitamin D metabolites. Ann Surg 229: 237-245.

4. Yamashita H, Noguchi S, Murakami T, Watanabe S, Uchino S, Ohshima A, Kawamoto H, Toda M (2000) Seasonal changes in calcium homeostasis affect the incidence of postoperative tetany in patients with Graves' disease. Surgery 127: 377-382.

5. Mosekilde L, Melsen F, Bagger JP, Myhre-Jensen O, Sorenson NS (1977) Bone changes in hyperthyroidism: interrelationships between bone morphology, thyroid function and calcium-phosphorous metabolism. Acta Endocrinol (Copenh) 85: 515-525.

6. Boonen S, Aerssens J, Dequeker J (1996) Age-related 
endocrine deficiencies and fractures of the proximal femur. II. Implications of vitamin D deficiency in the elderly. $J$ Endocrinol 149: 13-17.

7. Cummings SR, Nevitt MC, Browner WS, Stone K, Fox KM, Ensrud KE, Cauley J, Black D, Vogt TM (1995) Risk factors for hip fracture in white women. $N$ Engl J Med 332: 763-773.

8. Gloth FM, Gundberg CM, Hollis BW, Haddad JG, Jr, Tobin JD (1995) Vitamin D deficiency in homebound elderly persons. JAMA 274: 1683-1686.

9. Kinyamu HK, Gallagher JC, Balhorn KE, Petranick KM, Rafferty KA (1997) Serum vitamin D metabolites and calcium absorption in normal young and elderly free-living women and in women living in nursing homes. Am J Clin Nutr 65: 790-797.

10. Mosekilde L, Lund B, Sørensen OH, Christensen MS, Melsen F (1977) Serum 25-hydroxycholecalciferol in hyperthyroidism. Lancet 1: 806-807.

11. Velentzas C, Oreopoulos DG, From G, Porret B, Rapopart A (1977) Vitamin-D levels in thyrotoxicosis. Lancet 1: 370-371.

12. Bouillon R, Muls E, De Moor P (1980) Influence of thyroid function on the serum concentration of 1,25dihydroxyvitamin D3. J Clin Endocrinol Metab 51: 793-797.

13. MacFarlane IA, Mawer EB, Berry J, Hann J (1982) Vitamin D metabolism in hyperthyroidism. Clin Endocrinol (Oxf) 17: 51-59.

14. Jastrup B, Mosekilde L, Melsen F, Lund B, Lund B, Sørensen OH (1982) Serum levels of vitamin D metabolites and bone remodelling in hyperthyroidism. Metabolism 31: 126-132.

15. Haddad JG, Chyu KJC (1971) Competitive proteinbinding radioassay for 25 -hydroxycholecalciferol. $J$ Clin Endocrinol Metab 33: 992-995.

16. Halberg F, Tong YL, Johnson EA (1967) Circadian system phase-an aspect of temporal morphology. Procedures and illustrative examples. In: Mayersbach $\mathrm{H}$ (ed) The Cellular Aspect of Biorhythms. Springer, Berlin, 20-48.

17. Kobayashi T, Okano T, Shida S, Okada K, Suginohara T, Nakao H, Kuroda E, Kodama S, Matsuo T (1983) Variation of 25-hydroxyvitamin D3 and 25hydroxyvitamin D2 levels in human plasma obtained from 758 Japanese healthy subjects. J Nutr Sci Vitaminol (Tokyo) 29: 271-281.

18. Benucci A, Tommasi M, Fantappie B, Scardigli S,
Ottanelli S, Pratesi E, Romano S (1993) Serum 25hydroxyvitamin D levels in normal subjects: seasonal variations and relationships with parathyroid hormone and osteocalcin. J Nucl Biol Med 37: 77-82.

19. Matsuoka LY, Wortsman J, Hanifan N, Holick MF (1988) Chronic sunscreen use decreases circulating concentrations of 25-hydroxyvitamin D. A preliminary study. Arch Dermatol 124: 1802-1804.

20. Scragg R, Holdaway I, Singh V, Metcalf P, Baker J, Dryson E (1995) Serum 25-hydroxyvitamin D3 is related to physical activity and ethnicity but not obesity in a multicultural workforce. Aust N Z J Med 25: 218-223.

21. Stamp TC, Round JM (1974) Seasonal changes in human plasma levels of 25-hydroxyvitamin D. Nature 247: 563-565.

22. Poskitt EM, Cole TJ, Lawson DE (1979) Diet, sunlight, and 25-hydroxyvitamin D in healthy children and adults. Br Med J 1: 221-223.

23. Stryd RP, Gilbertson TJ, Brunden MN (1979) A seasonal variation study of 25-hydroxyvitamin D3 serum levels in normal humans. $J$ Clin Endocrinol Metab 48: 771-775.

24. Lester E, Skinner RK, Wills MR (1977) Seasonal variation in serum-25-hydroxyvitamin-D in the elderly in Britain. Lancet i: 979-980.

25. Krolner B, Vesterdal Jorgensen JV, Nielsen SP (1983) Spinal bone mineral content in myxoedema and thyrotoxicosis. Effects of thyroid hormone(s) and antithyroid treatment. Clin Endocrinol (Oxf) 18: 439-446.

26. Clements MR, Johnson L, Fraser DR (1987) A new mechanism for induced vitamin $\mathrm{D}$ deficiency in calcium deprivation. Nature 325: 62-65.

27. Gascon-Barré M, D'Amour P, Dufresne L, Perreault JP (1985) Interrelationships between circulating vitamin D metabolites in normocalciuric and hypercalciuric renal stone formers. Ann Nutr Metab 29: 289296.

28. Shafer RB, Gregory DH (1972) Calcium malabsorption in hyperthyroidism. Gastroenterology 63: 235239.

29. Takeuchi A, Okano T, Ishida Y, Masuda S, Miyata S, Fujii J, Tamai H, Mino M, Kobayashi T (1995) Positive effects of successive daily oral administration of a multivitamins preparation containing vitamin D2 for 4 weeks on vitamin D nutritional status in elderly subjects. Vitamins 69: 103-113. 